\title{
CEMENT-BASED WASTE FORMS FOR DISPOSAL OF SAVANNAH RIVER PLANT
} LOW-LEVEL RADIOACTIVE SALT WASTE

by

Christine A. Langton, Michael D. Dukes, and Randolph V. Simmons

E. I. du Pont de Nemours \& Co.

Savannah River Laboratory

Aiken, South Carolina 29808

A paper proposed for presentation (and publication) at the Materials Research Society Annual Meeting (and proceedings) Boston, Mass.

November $14-17,1983$

This paper was prepared in connection with work done under Contract No. DE-AC09-76SR00001 with the U.S. Department of Energy. By acceptance of this paper, the publisher and/or recipient acknowledges the U.S. Government's right to retain a nonexclusive, royalty-free license in and to any copyright covering this paper, along with the right to reproduce and to authorize others to reproduce all or part of the copyrighted paper. 
CEMENT-BASED WASTE FORMS FOR DISPOSAL OF SAVANNAH RIVER PLANT LOW-LEVEL RADIOACTIVE SALT WASTE

CHRISTINE A. LANGTON, MICHAEL D. DUKES, AND RANDOLPH V. SIMMONS E. I. du Pont de Nemours \& Company, Savannah River Laboratory, Aiken, South Carolina, USA 29808

\section{ABSTRACT}

Defense waste processing at the Savannah River Plant will include decontamination and disposal of approximately 100 million liters of soluble salts containing primarily $\mathrm{NaNO}_{3}, \mathrm{NaOH}, \mathrm{NaNO}_{2}, \mathrm{NaAl}(\mathrm{OH})_{4}$, and $\mathrm{Na}_{2} \mathrm{SO}_{4}$. A cement-based waste form, "saltstone," has been designed for disposal of Savannah River Plant low-level radioactive salt waste. Bulk properties of this material have been tailored with respect to salt leach rate, permeability, and compressive strength. Microstructure and mineralogy of leached and unleached specimens were characterized by SEM and X-ray diffraction analyses, respectively. It has been concluded that the salt leach rate can be limited so that amounts of salt and radionuclides in the groundwater at the perimeter of the 100 acre disposal site will not exceed EPA drinking water standards.

\section{INTRODUCTION}

\section{Background}

The Defense Waste Processing Facility (DWPF) at the Savannah River 1 Plant (SRP) is scheduled to begin operation in 1989. Two types of waste will be processed: high-level defense waste (primarily Fe, Mn, and A1 hydroxides) and low-level wasce (primarily sodium salts generated as spent industrial processing chemicals). The high-level waste amounts to about 10 million liters* of sludge which will be vitrified at SRP prior to shipment to a federal geologic repository.

The disposal process for low-level waste, primarily $\mathrm{NaNO}_{3}$, $\mathrm{NaNO}_{2}$, $\mathrm{NaAl}(\mathrm{OH})_{4}, \mathrm{Na}_{2} \mathrm{SO}_{4}$, and $\mathrm{NaOH}$, involves reconstitution of the salts into a concentrated solution (about 32 wt \% solids), decontamination, solidifica$t$ ion in a cement-based waste form, and burial at SRP. The average bulk composition of decontaminated aged salt solution is shown in Table $I$. The decontamination process consists of cesium removal by precipitation of cesium tetraphenyl borate and strontium removal by adsorption onto sodium titanate particles. Radionuclide concentrations in the average decontami- $t$ nated solution are 1 isted in Table II. The total projected amount of liquid waste, including salts generated by future plant operation, which will be disposed of in this manner is about 400 million liters.

\footnotetext{
* Future plant operation is expected to increase the total amount of
} sludge to about $24 \mathrm{million} 1$ iters by the year 2000 . 
TABLE I. Average chemical composition of decontaminated, aged salt solutiona

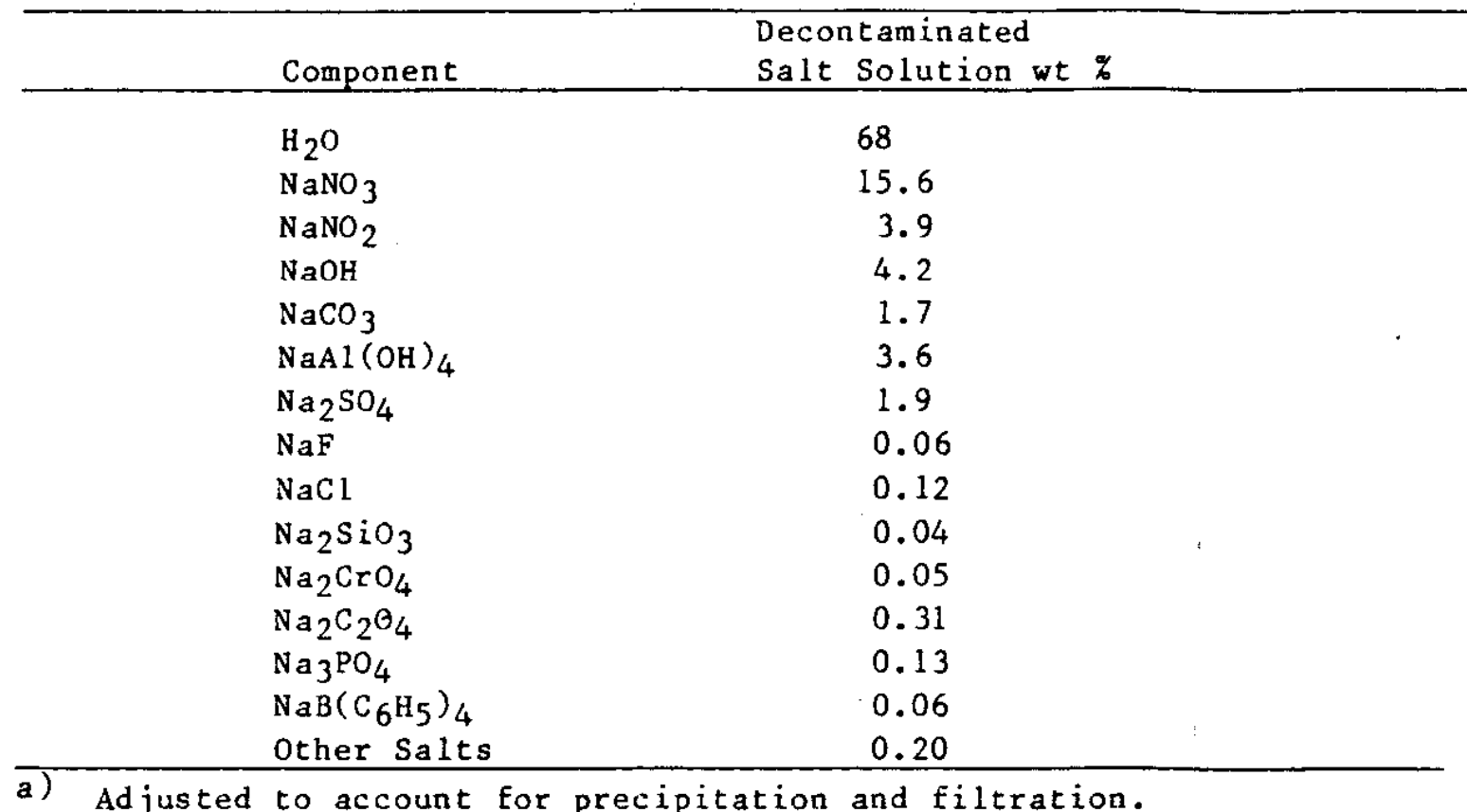

a) Adjusted to account for precipitation and filtration.

TABLE II. Average radionuclide composition of decontaminated, aged salt solution

\begin{tabular}{|c|c|}
\hline Radionuclide (half-life, yrs) & $\begin{array}{c}\text { Supernate (aged l5 yrs) } \\
\text { (nCi/g) }\end{array}$ \\
\hline${ }^{14} \mathrm{C}(5730)$ & 0.009 \\
\hline${ }^{60} \mathrm{Co}(5.27)$ & 0.2 \\
\hline${ }^{59} \mathrm{Ni}(80,000)$ & 0.0002 \\
\hline $63 \mathrm{Ni}(100)$ & 0.02 \\
\hline${ }^{79} \mathrm{Se}\left(\right.$ approx. $\left.6.5 \times 10^{4}\right)$ & 0.3 \\
\hline${ }^{90} \mathrm{Sr}(29)$ & 0.7 \\
\hline $90 \mathrm{Y}(3.1 \mathrm{hr})^{\mathrm{a}}$ & 0.7 \\
\hline $99 \mathrm{Tc}\left(2.1 \times 10^{5}\right)$ & $4 \times 10^{1}$ \\
\hline${ }^{106} \mathrm{Ru}(1.0)$ & $4 \times 10^{1}$ \\
\hline $106 \mathrm{Rh}(2.18 \mathrm{hr})^{\mathrm{a}}$ & $4 \times 10^{1}$ \\
\hline $125 \mathrm{Sb}(2.73)$ & 9 \\
\hline $126 \mathrm{Sn}$ (approx. $10^{5}$ & 0.2 \\
\hline $125 \mathrm{~m}_{\mathrm{Te}}(58 \mathrm{da})^{a}$ & 0.2 \\
\hline${ }^{126} \mathrm{Sb}(12.5 \mathrm{da})^{a}$ & 0.02 \\
\hline $125 \mathrm{~m}_{\mathrm{Sb}}(19 \mathrm{~min})$ & 0.2 \\
\hline${ }^{129} \mathrm{I}(1.7 \times 107)$ & 0.2 \\
\hline $137 \mathrm{Cs}(30.2)$ & $2 \times 10^{1}$ \\
\hline $137 \mathrm{~m}_{\mathrm{Ba}}(2.5 \mathrm{~min})^{\mathrm{a}}$ & $2 \times 10^{1}$ \\
\hline $147 \mathrm{Pm}(2.62)$ & 4 \\
\hline $151 \mathrm{Sm}(93)$ & 2 \\
\hline $154 \mathrm{Eu}(8.2)$ & 1 \\
\hline $155_{\mathrm{Eu}}(4.76)$ & 0.3 \\
\hline $238 \mathrm{Pu}(87.7)$ & 0.05 \\
\hline $239 \mathrm{gu}(24,000)$ & 0.0005 \\
\hline A11 TRU elements & 0.2 \\
\hline
\end{tabular}

a) Daughter of preceding isotope. 
The objective of this study was to design a material which incorporates salt and meets all state and federal requirements for low-level radionuclide and chemical waste disposal. Encapsulation materials initially considered for the waste form included; portland cement-based grouts, bitumen, and organic polymers. Portland cement grouts were selected because of flexibility in processing, good durability, and the ability to tailor the properties of the final product. The resulting waste form is referred to as saltstone.

\section{EXPERIMENTAL APPROACH}

Bulk properties of the cured saltstone have been tailored with respect to compressive strength, permeability, and leach rate. Rheological properties of the grout were also designed to produce a self-leveling slurry with an adjustable set time up to 4 hours. Minimal physical property requirements for a suitable saltstone material are shown in Table III. These physical property limitations were determined as the result of computer modeling of the saltstone landfill disposal system.*

TABLE III. Property Requirements of a saltstone waste form

\begin{tabular}{|c|c|}
\hline Property & Minimum Value \\
\hline Compressive Strength & $1 \mathrm{MPa}$ \\
\hline Permeability & $10^{-10} \mathrm{~cm} / \mathrm{sec}$ \\
\hline Bulk Leach Rate & $10^{-5} \mathrm{~g} / \mathrm{cm}^{2}-$ day \\
\hline Apparent Viscosity & 300 dynes $/ \mathrm{cm}^{2}$ maximum at $300 \mathrm{rpm}$ \\
\hline Set Time & Adjustable up to 4 hours \\
\hline
\end{tabular}

Initial characterization involved laboratory testing of several types of cement-based waste forms including neat cement, soil-cement and blended cement grouts. Simulated salt solution (nonradioactive) with the composi$t$ ion shown in Table $I$ was used as the mixing solution. Mixing was conducted in accordance with the API standard procedure [1]. Formulations were screened on the basis of compressive strength, permeability, leach rate, and slurry rheology. Tests were conducted on samples cured for 28 days at room temperature and $>95 \%$ relative humidity. Compressive strength measurements were conducted according to ASTM procedure C-109. Water permeability measurements were made by a modified API method, and salt leach rate analyses were conducted by the MCC-1 procedure [2]. The resulting leachate was analyzed for $\mathrm{NO}_{3}{ }^{-}$. Sodium nitrate was the most soluble constituent in the waste form; therefore, unless supported by specific data, other salts and the radionuclides were assumed to leach at a rate equivalent to that of $\mathrm{NaNO}_{3}$.

* The current plan is to emplace saltstone in trenches above the water table and 5 meters below grade at SRP. The saltstone monoliths will be covered with a bentonite cap; native soil will be backfilled and compacted to the original grade. 
Microstructural analyses were carried out by SEM imagery of freshly fractured surfaces after $3,7,14,28$, and 60 days curing. Changes in the microstructure as a function of increasing degree of cement hydration were correlated with bulk property measurements. Distribution of salts and the manner of salt incorporation in the waste form were also documented by SEM and by powder pattern $x$-ray diffraction analyses.

\section{RESULTS AND DISCUSSION}

\section{Property Measurements}

Examples of formulations for each type of cement-based waste form tested are shown in Table IV. Proportions in these examples were determined by preliminary screening experiments. The set time of the neat portland cement grout was severely accelerated by the high concentration of sodium salts ( 32 wt \%) in the mixing solution. Premature set affected the properties of the cured material in addition to the rheology of the slurry. Low compressive strengths and high permeabilities of the neat cement grouts were due to the heterogeneous microstructure resulting from the initial premature set phenomena. In the most severe cases, heterogeneity was observed on a macroscopic scale as illustrated in Figure 1. Similar results

TABLE IV. Selected portland cement grouts containing SRP salt solution

\begin{tabular}{lllll}
\hline Ingredient & $\begin{array}{l}\text { Neat Cement Grout } \\
\text { Type I } \\
(\text { wt } \%)\end{array}$ & $\begin{array}{l}\text { Type I-P } \\
(\text { wt } \%)\end{array}$ & $\begin{array}{l}\text { Soil Cement Grout } \\
(\text { wt \%) }\end{array}$ & $\begin{array}{l}\text { Blended } \\
\text { Cement Grout } \\
\text { (wt \%) }\end{array}$ \\
\hline Cement & 51.1 & 51.11 & $22.8(\mathrm{I}-\mathrm{P})$ & 62 \\
Aggregate & - & - & $39.2^{\mathrm{b}}$ & - \\
Solution & 48.5 & 48.5 & 37.8 & $38^{\mathrm{a}}$ \\
Admixture & $0.4^{\mathrm{c}}$ & $0.4^{\mathrm{c}}$ & $0.2^{\mathrm{c}}$ & - \\
\hline
\end{tabular}

a) 20 wt \% Type I or Class H cement plus 80 wt \% Class C flyash.

b) $80 \mathrm{wt} \%$ quartz sand, 20 wt \% kaolin clay.

c) Pozzolith 122-R, (Master Builders), Plasticizer - Set Retarder.

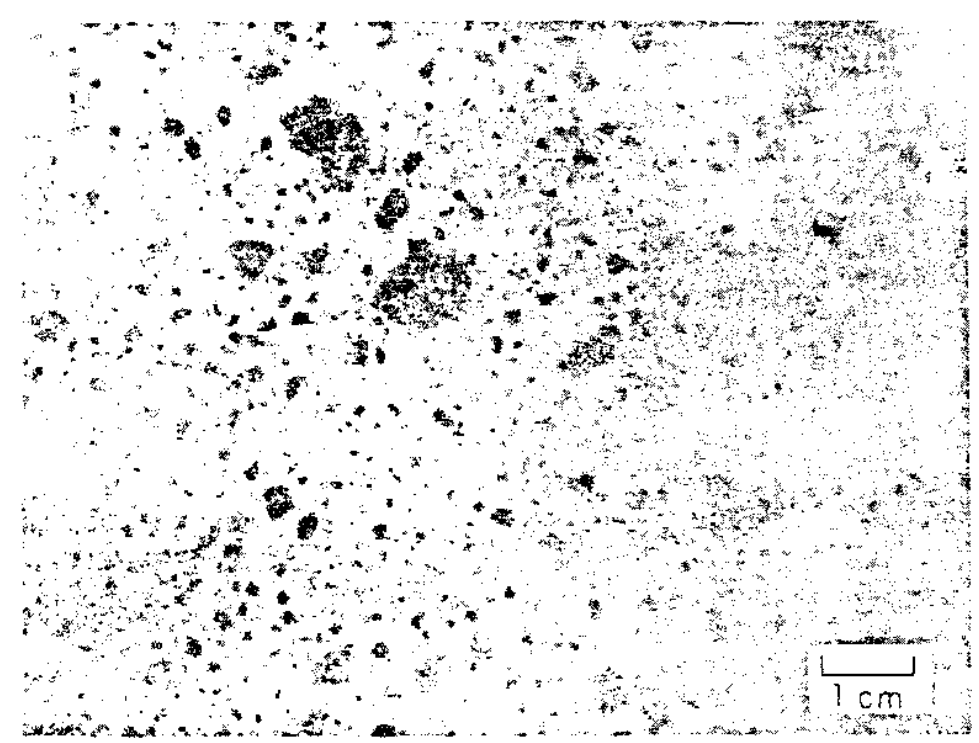

Fig. 1. Example of macroscopic inhomogeneity of Type I cement grout caused by false set. 
were obtained for grouts containing Type I-P cement (Type I-P contains approximately $80 \%$ Type I cement plus $20 \%$ Class F flyash). Physical property data representative of these grouts are 1 isted in Table $V$.

TABLE V. Examples of Properties measured for cement - SRP salt solution grouts cured 28 days

\begin{tabular}{llllll}
\hline & $\begin{array}{l}\text { Compressive } \\
\text { Strength } \\
(\mathrm{MPa})\end{array}$ & $\begin{array}{l}\text { Permeability } \\
(\text { Water }) \\
(\mathrm{cm} / \mathrm{sec})\end{array}$ & $\begin{array}{l}\text { Initial } \\
\text { Leach Rate } \\
\left(\mathrm{g} / \mathrm{cm}^{2}-\text { day }\right)\end{array}$ & $\begin{array}{l}\text { Long Term } \\
\left(\mathrm{g} / \mathrm{cm}^{2}-\mathrm{day}\right)\end{array}$ & $\begin{array}{l}\text { Set } \\
\text { Mr } \mathrm{hr})\end{array}$ \\
\hline
\end{tabular}

Neat Cement

Grout

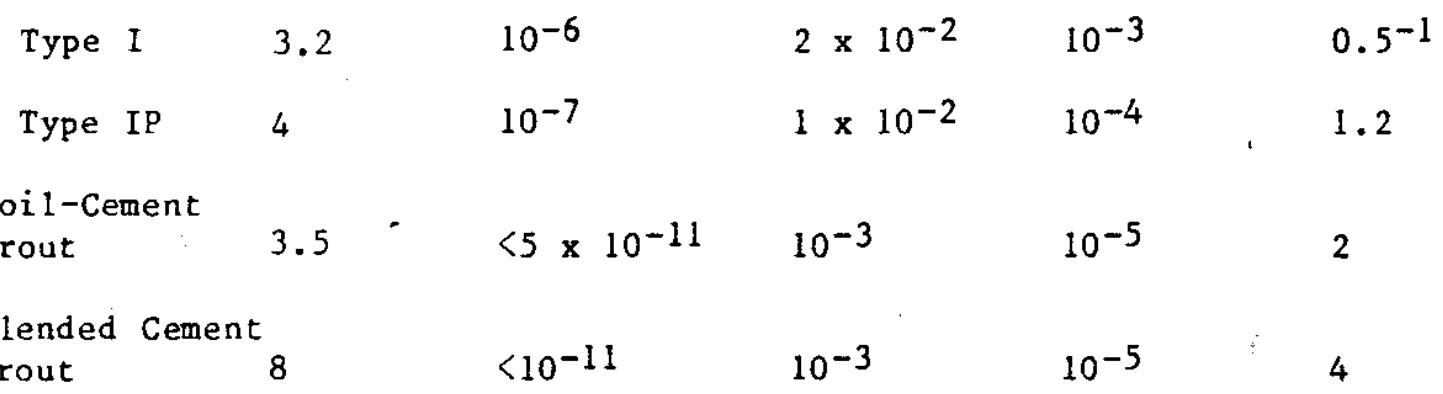

Since it was not practical to control the slurry rheology by a 50 to 100 times dilution of the waste solution or by the addition of large quantities (2-4 wt \%) of organic set retarders, dilution of the portland cement component was tested as a means of slowing the initial hydration reaction.* Several types of reactive and unreactive aggregates including sand, flyash, soil, bentonite, metakaolin, and slag were evaluated in saltstone formulations. SRP soil and flyash were most effective in achieving mixtures with the desired low permeabilities and low heats of hydration. Local soils with about 80 wt \% quartz sand and 20 wt \% kaolin clay, and Class C or F , flyashes produced saltstone formulation which met the specified property requirements. Physical property data for a soil-cement grout and a grout containing 80 wt \% Class C flyash are presented in Table $\mathrm{V}$.

Type I-P cement was used in the soil-cement mixtures since the leach rates of Type I-P grouts were lower than those for Type I grouts. Water permeabilities of less than $5 \times 10^{-10} \mathrm{~cm} / \mathrm{sec}$ were measured for samples cured for 28 days at room temperature and $>95 \%$ RH. This is an improvement of about two orders of magnitude compared to the neat Type I-P grouts. High-shear mixing of the soil-cement formulations resulted in dispersion of the very fine, clay fraction (kaolin particle size < $1 \mathrm{\mu m}$ ). Incorporation of these fine particles in the cement matrix effectively sealed the pore spaces and reduced the water permeability. The massive microstructure of a soil-cement formulation which was cured for 28 days is illustrated in Figure 2. The addition of the unreactive soil component also effectively lowered the heats of hydration of these mixes. Although the compressive strengths of the cured product were reduced somewhat relative to the neat cement grouts, measured values of $3.5 \pm 1.5 \mathrm{MPa}$ were well above the design limits for the monolith.

* In actual mixing tests, two methods of controlling the effects of false set were necessary, i.e. dilution of the portland cement in a given volume of solution and high-shear mixing. The effect of high-shear mixing is to "mix through" the initial set. Both practices are among the routine field procedures for controlling false set. 


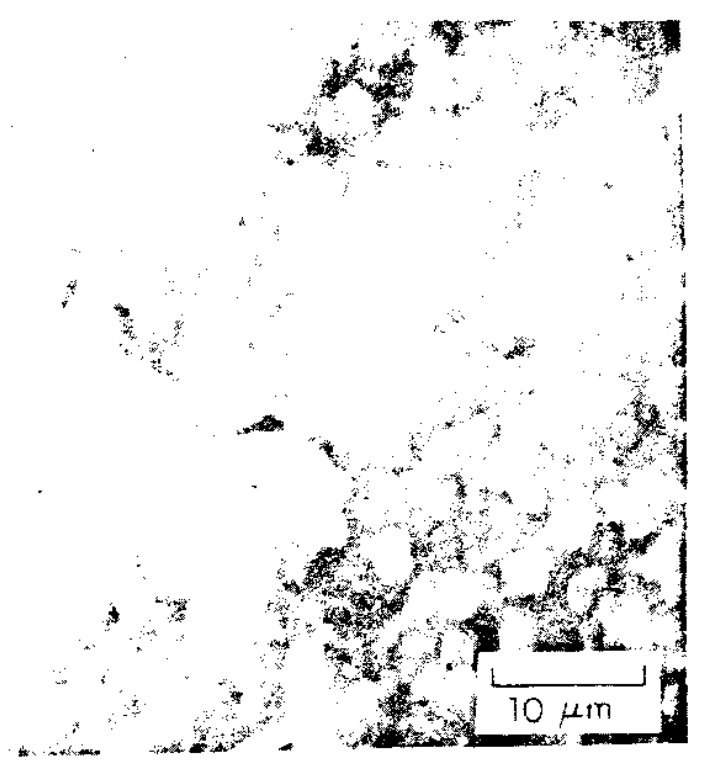

Fig. 2. Microstructure of grout containing 40 wt $\%$ SRP soil, 22 wt \% portland I-P cement, and 38 wt \% salt solution cured 28 days, at $20^{\circ} \mathrm{C},>95 \%$ RH. Interstitial sodium salt crystals are imbedded in the matrix.

Specially blended formulations containing portland cement plus $>50$ wt \% pozzolan were also tested. These mixtures offer considerable flexibility in formulation design since both the proportioning and the type of pozzolan can be adjusted to obtain a suitable product. Proportioning for one blended cement formulation is shown in Table IV. By using a mixture of Class $\mathrm{H}$ cement ( 20 wt \%) and Class C flyash ( 80 wt \%), a selfleveling grout containing $>90 \%$ cementitious material was produced. Since the flyash reacts to form calcium silicate gel (CSH) at a slower rate than portland cement, the need for set retarding admixtures is minimized. Within 28 days of curing at room temperature and $>95 \% \mathrm{RH}$, sufficient reaction of the flyash and cement occurred to achieve water permeabilities of less than $10^{-11} \mathrm{~cm} / \mathrm{sec}$ and compressive strength of $10 \pm 1 \mathrm{MPa}$. SEM photomi crographs shown in Figure 3 illustrate changes in the microstructure of

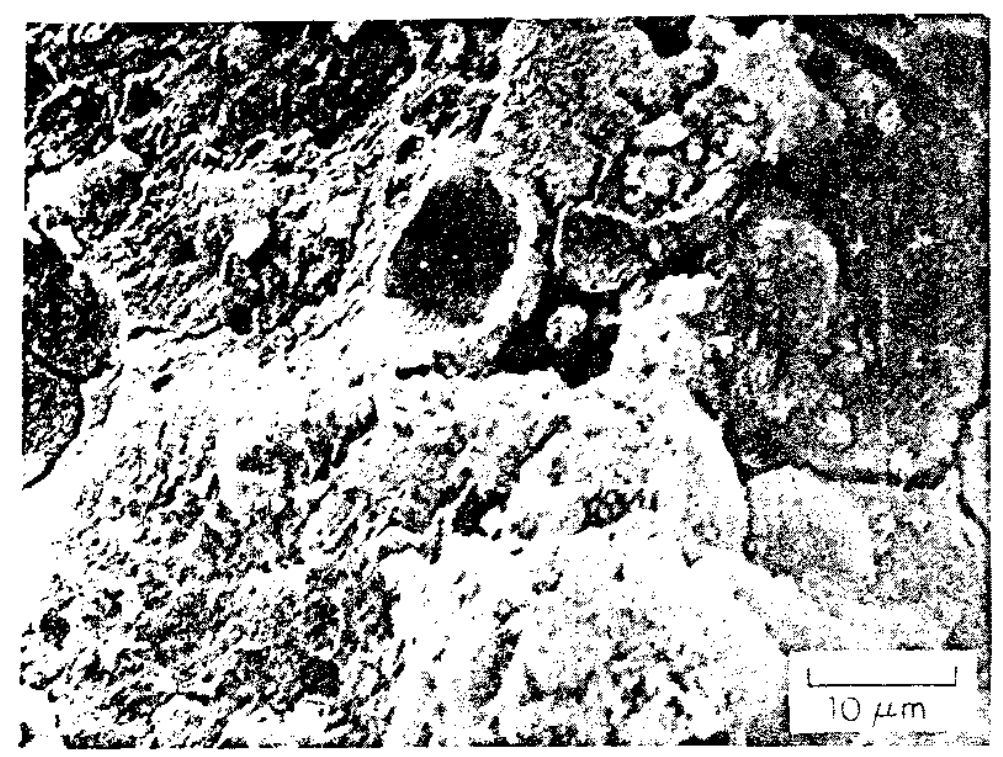

Fig. 3. Microstructure of grout containing 62 wt $\%$ cement ( $20 \% \mathrm{Class} \mathrm{H}$ cement $+80 \%$ Class C flyash) and 38 wt $\%$ salt solution cured 28 days. Salt crystals are present as interstial matrix phases. Partially reacted flyash is also present. 
this blended cement grout between 3 and 28 days. As a result of an increasing degree of hydration, a more massive microstructure was observed in the 28-day samples. In addition, as water is consumed in the hydration reactions, sodium salts precipitate as interstitial crystals within the CSH gel matrix and in pore spaces.

Contaminant Release Rates

Leaching experiments were conducted under relatively severe conditions in order to screen potential formulations and to evaluate performance under worst case conditions. Experiments consisted of leaching $250 \mathrm{~g}$ samples in $500 \mathrm{ml}$ of deionized water. Water was changed daily for the first week, weekly for two months, and then monthly for at least one year. Leachate was analyzed for nitrate by ion chromatography. Results for representative soil cement, neat cement, and blended cement grouts are shown in Figure 4. Leach data were used to calculate contaminant release from the reference disposal site and to estimate total ion release rates which are summarized in Table VI [3]. EPA drinking water standards are also shown in Table VI for comparison. As illustrated, the projected contaminant release rates are well below drinking water limits.

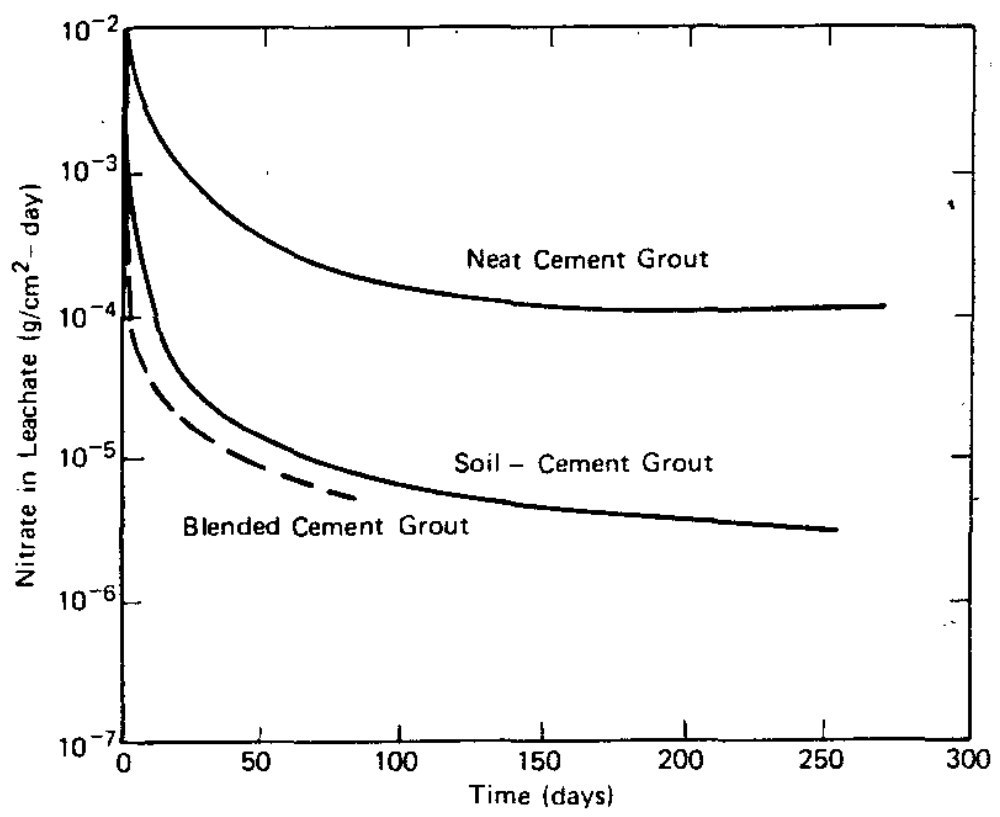

Fig. 4. Nitrate leach rate of salt-containing cement formulations.

TABLE VI. Calculated contaminant releases from saltstone

\begin{tabular}{lllll}
\hline Element & (Unit) & $\begin{array}{l}\text { Concentration } \\
\text { in Saltstone }\end{array}$ & $\begin{array}{l}\text { Total } \\
\text { Groundwater } \\
\text { Content }\end{array}$ & $\begin{array}{l}\text { EPA } \\
\text { Drinking Water } \\
\text { Standards }\end{array}$ \\
\hline $\mathrm{NO}_{3}{ }^{-}$ & $(\mathrm{ppm})$ & 37,200 & 0.06 & 44 \\
$\mathrm{Cr}$ & $(\mathrm{ppm})$ & 50 & $1 \times 10^{-4}$ & 0.05 \\
$\mathrm{Hg}$ & $(\mathrm{ppm})$ & 0.004 & $1 \times 10^{-8}$ & 0.002 \\
${ }^{90} \mathrm{Sr}$ & $(\mathrm{pCi} / \mathrm{L})$ & $3 \times 10^{5}$ & 0.008 & 8 \\
${ }^{99} \mathrm{TC}$ & $(\mathrm{pCi} / \mathrm{L})$ & $2 \times 10^{4}$ & 45 & 900 \\
$129 \mathrm{I}$ & $(\mathrm{pCi} / \mathrm{L})$ & $3 \times 10^{4}$ & 0.1 & 1 \\
$137 \mathrm{Cs}$ & $(\mathrm{pCi} / \mathrm{L})$ & $1 \times 10^{7}$ & 32 & 200 \\
\hline
\end{tabular}


Saltstone, a cement-based waste form, has been designed for disposal of low-level radioactive salt waste at SRP. This material contains portland cement, flyash, and salt solution containing about 32 wt \% sodium salts. Physical properties, mineralogy, and microstructure of the saltstone are similar to those of conventional grouts which contain soluble salts as interstitial crystals in the cement matrix. In addition, processing utilizes conventional high-volume grout equipment and techniques. The saltstone product in combination with design of the total landfill meets all state and federal guidelines for contaminant release into the environment $[4,5,6,7]$.

\section{ACKNOWLEDGMENT}

The information contained in this article was developed during the course of work under Contract No. DE-AC09-76SR0000l with the U.S. Department of Energy.

\section{REFERENCES}

1. API Specification for Materials and Testing for Well Cements, Am Petroleum Institutes, Dallas, TX (1982).

2. D. M. Strachan, B. O. Barnes, and R. P. Turcotte, "Standard Leach Tests for Nuclear Waste Materials," Sci. Basis for Nuclear Waste Management, V. 3 Plenum Press, NY, pp. 347-354 (1981).

3. M. D. Dukes, H. C. Wolf, and C. A. Langton, "Disposal of Decontaminated Salts at the Savannah River Plant by Solidification and Burial," 1983 Winter Meeting of the Am. Nuclear Society, San Francisco, CA (October 1983).

4. "Radioactive Waste Management (DRAFT)," U.S. Department of Energy. DOE Order 5820 (March 25, 1983).

5. "Hazardous Waste Management," U.S. Department of Energy. DOE Order 5480 (December 1982).

6. "National Interim Primary Drinking Water Regulations," U.S. Environmental Protection Agency. EPA 570/9-76-003 (1975).

7. "Hazardous Waste Management Regulations," South Carolina Department of Health and Environmental Control. March 31, 1980 (amended January 29, 1981). 